\title{
НЕКОТОРЫЕ АСПЕКТЫ ВЛИЯНИЯ СОVID-19 НА ПСИХИЧЕСКОЕ ЗДОРОВЬЕ ЧЕЛОВЕКА
}

\author{
Гараева Светлана Николаевна \\ Кандидат биологических наук, \\ ведущий научный сотрудник, \\ Институт физиологии и санокреатологии, \\ 2. Китинев \\ Леорда Анна Ивановна \\ Кандидат биологических наук, \\ ведущий научный сотрудник, \\ Институт физиологии и санокреатологи, \\ 2. Китинев \\ Постолати Галина Васильевна \\ научный сотрудник, \\ Институт физиологии и санокреатологии, \\ 2. Кишинев
}

\begin{abstract}
Аннотация. Охрану психического здоровья необходимо поставить во главу угла в усилиях каждой страны по борьбе с пандемией COVID-19 и последующего восстановления. В настоящий момент особую важность приобретает своевременная профилактика «коронавирусного синдрома», для прогнозирования наступления которого, можно предложить использование анализа свободных аминокислот крови, что позволяет оценить баланс тормозных и возбуждающих процессов мозга, оценку функциональной активности щитовидной железы, а также определение уровня активности антиоксидантной системы и адаптационного потенциала организма.

Summary. Mental health needs to be at the forefront of every country's efforts to tackle and recover from the COVID19 pandemic. Currently, timely prevention of the "coronavirus syndrome" is of particular importance, for predicting the onset of which, it is possible to propose the use of an analysis of free blood amino acids, which makes it possible to assess the balance of inhibitory and excitatory processes in the brain, assess the functional activity of the thyroid gland, as well as determine the level of activity of the antioxidant system adaptive potential of the organism.
\end{abstract}

Ключевые слова: психическое здоровье, коронавирусный синдром, реакция на стресс, свободные аминокислоты

Key words: Mental health, coronavirus syndrome, stress response, free amino acids

Несмотря на то, что кризис, вызванный COVID-19, угрожает в первую очередь физическому здоровью, он может стать причиной серьезных проблем в области психического здоровья, если не будут приняты соответствующие меры. Поскольку крепкое психическое здоровье имеет огромное значение для функционирования общества, его охрану необходимо поставить во главу угла в усилиях каждой страны по борьбе с пандемией COVID-19 и последующего восстановления. В настоящий момент психическое здоровье и благополучие целых сообществ серьезно пострадали в результате этого кризиса, и забота о них входит в число приоритетных задач, требующих срочного решения [2, с. 2].

Заболевание короновирусом SARS-CoV-2, несомненно, можно отнести к состояниям, которые приводят к изменению стереотипа поведения. У лиц, обнаруживающих депрессивные или тревожные расстройства, обнаружен ослабленный иммунитет, что повышает опасность заражения вирусом. Для инфицированных лиц характерна острая реакция на стресс, могут возникать расстройства адаптации, смешанное тревожное и депрессивное расстройство [1, с. 4]. Признаки, свидетельствующие о делирии, распространены в острой стадии SARS, MERS и COVID-19, также есть свидетельства депрессии, тревоги, усталости и посттравматического стрессового расстройства на стадии после болезни предыдущих эпидемий коронавируса, но данных по COVID19 пока мало. Кроме того, при SARS-CoV-инфекции может иметь место гипервоспалительное состояние, а связь между воспалением и депрессией хорошо описана и может объяснить некоторые психические заболевания [11]. Некоторые американские исследователи [9] предположили, что коронавирус может манипулировать поведением инфицированных людей, иногда даже до того, как у них проявляются симптомы, чтобы они стали более общительными. Согласно этой теории, вызывающий COVID-19 вирус может атаковать наш мозг и изменить наше поведение в инкубационный период, когда люди инфицированы, но не проявляют никаких симптомов, поэтому они с большей вероятностью будут общаться, тем самым ускорив вспышку заболевания. Таким образом, патогены максимизируют скорость своего воспроизводства (известную как R0) и, в свою очередь, их распространение и выживаемость. Полагают, что вирус может воздействовать на переднюю поясную кору мозга, которая участвует в социальном поведении и эмоциональной регуляции. COVID может также влиять на эндокринную систему (в частности, щитовидную железу), которая вырабатывает гормоны, регулирующие многие функции, от сна до репродукции и социального поведения [5]. Есть предположение, что SARS-CoV-2 проникает через обонятельную 
луковицу - область мозга, отвечающую за восприятие запахов, - и достигает ствола мозга, убивая нейроны. Молекулы-предшественники воспаления (цитокины) могут вызвать бурную реакцию организма - цитокиновый шторм - и повредить мозг. Вот почему, по мнению Де Сантиса, врачи должны быть готовы к тому, что состояние больных COVID-19 с потерей обоняния ухудшится [3]. Кроме того, на фоне пандемии COVID-19 в обществе появился новый навязчивый страх - коронафобия. Таким образом, пандемия обладает отсроченным эффектом. Постстрессовые расстройства могут проявиться как через несколько месяцев, так и через несколько лет после ее окончания. Финансовые трудности, связанные с экономическими последствиями пандемии, будут главным фактором, определяющим эмоциональные нарушения в постпандемическом пространстве. Более того, у некоторых людей более значительную тревогу, вызывают реально существующие экономические трудности, чем потенциальная возможность заразиться коронавирусом. Картину психических проявлений «коронавирусного синдрома» можно разделить на несколько этапов [4, с. 20]. Первылй этап - это острая реакция на стресс. Эта реакция длится весь период существования угрозы, она наблюдается уже сейчас и будет идти на спад с улучшением эпидемиологической обстановки и снятием карантинных мер. Острая реакция проявляется спектром состояний - от паники и утрирования проблемы до ее отрицания. Существует несколько вариантов ответа организма на стресс: в текущей ситуации. У одного типа людей это ступор, сужение сознания, заторможенность, негативные прогнозы, у другого типа - оживленность, словоохотливость, признаки гипоманиакального состояния и возбуждения. Отчетливо видно «коронавирусное» единение в социальных сетях, обилие юмористического и шуточного контента, но в то же время многие испытывают тревогу, связанную со страхом заражения и страхом смерти. В ряде случаев у людей снижается критичность мышления, события интерпретируются с позиции мистики и теорий заговоров. Многие отмечают измененное чувство времени (один день будто бы длится бесконечно) и нарушения сна (трудности засыпания, прерывистый сон, кошмарные сновидения), снижение мотивации и чувство потерянности. У людей с психическими заболеваниями в анамнезе вероятны обострения психических расстройств. У значительной части людей данный этап ограничится мобилизацией сил, сопровождающейся специфическими биологическими изменениями в организме без клинических проявлений.

На этом этапе возрастает роль свободных аминокислот. Значение аминокислот для организма определяется тем, что они используются для синтеза белков, метаболизм которых занимает особое место в процессах обмена веществ между организмом и внешней средой. Белки входят во все структурные компоненты клеток, тканей и органов, выполняют ферментативные функции, участвуют в переносе веществ через мембраны и т. д. Важную роль в координации работы всех систем клеток играют белковые гормоны. Аминокислоты участвуют в биосинтезе большого количества других биологически активных соединений, регулирующих процессы обмена веществ в организме - нейромедиаторы, гормоны. Аминокислоты служат донорами азота при синтезе всех азотсодержащих небелковых соединений: нуклеотидов, гема, креатина, холина и других веществ. Энергетическая функция аминокислот становится значимой при некоторых патологических состояниях - сахарный диабет и других. В аспекте формирования тревожных и депрессивных состояний особенное значение приобретают медиаторные аминокислоты. В первую очередь, рецепторы $\gamma$-аминомасляной кислоты (ГАМК) из-за избыточной нагрузки становятся менее чувствительными к аффинному медиатору ГАМК, что приводит к нарушению физиологических процессов торможения в ЦНС и повышению уровня тревоги [8, с. 1124].

Глицин также является регулятором обмена веществ, нормализует процессы возбуждения и торможения в центральной нервной системе, обладает антистрессорным эффектом, повышает умственную работоспособность, и его недостаток в организме при нарушениях питания или всасываемости неизбежно сказывается на психическопм состоянии человека. Фенилаланин - незаменимая аминокислота, которая может превращаться в тирозин, который, в свою очередь, используется в синтезе двух основных нейромедиаторов: допамина и норадреналина. Влияет на настроение, уменьшает боль, улучшает память и способность к обучению, подавляет аппетит. Тирозин является предшественником нейромедиаторов норадреналина и дофамина, участвует в регуляции настроения. Недостаток тирозина приводит к дефициту норадреналина, что приводит к депрессии. Снижение концентрации таурина в крови вызывает маниакально-депрессивный синдром, депрессивные неврозы.

Поэтому нарушение обмена этих аминокислот изменяет работу всей моноаминергической системы, что приводит к дисфункции серотонина, дофамина, норадреналина, уменьшается концентрация кортизола в плазме крови (в связи с индукцией отрицательной обратной связи по гипоталамо-питуитарно-адреналовой оси). При длительной стрессовой ситуации в данном периоде может развиваться расстройство адаптации, которое может проявляться повышенной тревожностью и напряженностью, беспокойством, депрессивным настроением, астенией, но при этом не достигать развернутой картины тревожных и депрессивных расстройств. Bторой этап является переходным. Наступает только после исчезновения реальной угрозы, будет зависеть от степени изменения динамического стереотипа жизни, жизненного уклада и степени биологических изменений, произошедших во время первого этапа. Часть людей переживет его подостро, с внутренним эмоциональным напряжением, изменением пищевого поведения, нарушениями сна, достаточно часто может сохраняться или возникать описанное выше расстройство адаптации. У другой части может развиться депрессия или тревожное расстройство. Третий этап - это отсроченная реакция на стресс, которая развивается спустя месяц или полгода после окончания пандемии. Она может возникать и у людей, которые не имели никаких психических расстройств 
на первых двух этапах. При этом, можно выделить следующие клинические проявления: личностная и социальная дезориентация; чувство потери смысла жизни; раздражительность, эмоциональная лабильность; заострение личностных особенностей; депрессия, апатия, снижение общего тонуса и работоспособности, маниакальные проявления; усиление психоэмоционального напряжения, тревожности и беспокойства; чрезмерная бдительность ко всему, что кажется угрожающим по отношению к здоровью, личному пространству, финансовому благополучию. На этом этапе особенно актуальными станут жалобы на нарушения внимания, трудности запоминания, удерживание в памяти той или иной информации, трудности ее воспроизведения. Это связано не напрямую с нарушениями памяти, а с тем, что внимание человека фиксировано на пережитом, не распространяется на настоящие события жизни, не может переключиться на текущие задачи и проблемы. Из-за этого будут страдать трудоспособность, общение, образ жизни. Повышается степень внушаемости. Клинические проявления могут быть более серьезными у врачей, работающих с COVID, у людей, потерявших родных и близких, место работы или свой бизнес. В этом случае появляется больше шансов воспринять ситуацию как непосредственную травму, что приводит к повышению риска формирования развернутой картины посттравматического стрессового расстройства (ПТСР) с такими серьезными симптомами, как: навязчивые и угнетающие воспоминания о событиях, снова и снова повторяющиеся переживания ярких моментов, связанных с эпидемией, иногда флешбэки - внезапные, яркие, повторные переживания, которые трудно отличить от действительности, сопровождающихся помрачением сознания и агрессией; переживание неизбежности утраты, собственного бессилия; тяжелые сновидения, нарушения засыпания, ночные пробуждения и ранние пробуждения в состоянии тревоги; страх повторения пережитого кошмара, фобии, панические атаки; значимое падение работоспособности и апатия, либо развитие гиперастении. На данном этапе возможны личностные и биологические изменения. Личностные - характеризуются снижением настроения, отсутствием интереса к новому, к ранее значимой активности, пессимизмом, сложно увидеть перспективы развития, что вызывает раздражительность, вспышки злобы, поиском виновных на стороне или попыткой определить степень своей виновности, вплоть до самобичевания. Нарушение обмена свободных аминокислот, в частности, гликогенных и иммуноактивных, приводит к возникновению или обострению уже имеющихся соматических заболеваний. Так, лизин, незаменимая аминокислота, входящая в состав практически любых белков, участвует в производстве антител, гормонов, ферментов, альбуминов, оказывает противовирусное действие, поддерживает уровень энергии, участвует в формировании коллагена и восстановлении тканей, улучшает усвоение кальция из крови и транспорт его в костную ткань. Цистин в организме является важной частью белков, таких как иммуноглобулины, инсулин и соматостатин. Аланин является важным источником энергии для головного мозга и центральной нервной системы; укрепляет иммунную систему путем выработки антител; активно участвует в метаболизме сахаров и органических кислот и в регуляции уровня сахара в крови. Поэтому его избыток или недостаток в крови может вести к преддиабету или диабету, что является характерным явлением состояния хронического стресса.

Подобные изменения аминокислотного обмена у инфицированных людей связаны с тем, что SARS-Cov-2 способен проникать и в другие органы, отвечающие за метаболизм глюкозы в организме, например, тонкий кишечник, липидные ткани, печень и почки, где он провоцирует дисфункции обмена веществ и кишечные заболевания [7, с. 20]. Кроме того, на фоне острого респираторного синдрома, вызванного SARS-CoV-2, ухудшение показателей глюкозы крови характерно как для диабетиков, так и для недиабетиков. В России порядка $20 \%$ населения имеют преддиабетические стадии сахарного диабета. Если они заболеют коронавирусной инфекцией, можно ожидать резкого прироста людей, страдающих диабетом.

Биологические изменения с повышением патологической активности головного мозга на этом этапе можно увидеть на электроэнцефалограмме в виде увеличения спектральной мощности и снижения когерентности между височными, височно-теменными и теменно-лобными отделами головного мозга [10, с. 244], тенденции к общей десинхронизации: увеличение мощности $\beta$-ритма, снижение относительной представленности $\alpha$-диапазона [6, с. 770].

Таким образом, возможные осложнения и изменения личности, к которым приведет «коронавирусный синдром», будут связаны не только со снижением качества жизни, социального функционирования человека, но и с формированием стойкой утраты трудоспособности, удлинением стрессовой реакции, невротизацией и психопатизацией личности, а также с переходом невротического расстройства в органическое (особенно при употреблении психоактивных веществ). Присутствует риск не только утраты пластичности общения и способности приспосабливаться к происходящему, заострения личностных особенностей (формирования эксплозивных, истерических, демонстративных или шизоидных черт характера), но и появления цинизма, склонности к антисоциальным действиям или бездействию, ограничения коммуникаций, зачастую на фоне алкоголя и/или наркотиков.

Анализ литературы позволяет сделать заключение, что «коронавирусный синдром» - это психическое расстройство, представляющее собой реакцию на пандемию COVID-19, которое затронет до $10 \%$ пострадавшего населения [4, с. 19]. Уже сейчас можно наблюдать острые стрессовые реакции на фоне распространения инфекции и изменений привычного уклада жизни. Однако наиболее тяжелые проявления наблюдались через 6 месяцев после начала катастрофы, они аналогичны по своей клинической картине посттравматическому стрессовому 
расстройству. Опасность «коронавирусного синдрома» в том, что он будет снижать работоспособность населения именно тогда, когда она будет крайне важна для восстановления экономики. Группой риска являются: медицинские работники, оказывающие помощь пациентам с COVID; лица, переболевшие тяжелой формой заболевания; люди, потерявшие родственников и близких, а также те, кто понес значительные финансовые потери и лишился

места

работы

$[2$, c. $6-7 ; 4$, c. 21$]$.

Таким образом, особую важность приобретает своевременная профилактика «коронавирусного синдрома», заключающаяся в фармакотерапии и психотерапевтической поддержке. Для прогнозирования наступления такого состояния можно предложить использование анализа свободных аминокислот крови, с помощью которого возможно оценить баланс тормозных и возбуждающих процессов мозга, оценку функциональной активности щитовидной железы, а также определение уровня активности антиоксидантной системы (глутатион) и адаптационного потенциала организма (карнозин).

\section{Список литературы:}

1. Агамамедова И.Н., Банников Г.С, Клещян К.Л. и др. Психические реакции и нарушения поведения у лиц c COVID-19. Информационное письмо. Московский НИИ психиатрии. М. 2020.9 с.

2. Аналитическая записка: COVID-19 и необходимость принятия мер по охране психического здоровья. Резюме. 2020, 20 c.

3. Пичугина Т. Ученые доказали, что коронавирус повреждает мозг. Какие последствия? 2020 https://ria.ru/20201209/mozg-1588209192.html.

4. Соловьева Н.В., Макарова Е.В., Кичук И.В. «Коронавирусный синдром»: профилактика психотравмы, вызванной COVID-19 //РМЖ «Медицинское обозрение» №9, 2020, стр.18-22.

5. Яшлавский А. Влияние коронавируса на мозг и поведение людей удивило ученых. https://www.mk.ru/science/2020/11/24/vliyanie-koronavirusa-na-mozg-i-povedenie-lyudey-udivilo-uchenykh.html.

6. Atlantis E., Fahey P., Cochrane B., Smith S. Bidirectional associations between clinically relevant depression or anxiety and chronic obstructive pulmonary disease (COPD): a systematic review and meta-analysis. Chest. 2013;144(3):766-777.

7. Barron E., Bakhai Chirag, Kar Partha, et al. Associations of type 1 and type 2 diabetes with COVID-19-related mortality in England: a whole-population study https:// The Lancet. Diabetes and Endocrinology August 2020, p.18-29.

8. Bremner J.D., Innis R.B., Southwick S.M. et al. Decreased benzodiazepine receptor binding in prefrontal cortex in combat-related posttraumatic stress disorder. //Am J Psychiatry. 2000;157:1120-1126.

9. Dobson R. Can viruses change our behaviour? From Covid-19 to colds, the astonishing truth of how infections trick us into spending more time socialising (and spreading germs!) //The Daily Mail. 2020.

10. Lee T.W., Yu Y.W., Chen M.C., Chen T.J. Cortical mechanisms of the symptomatology in major depressive disorder: A resting EEG study. Journal of Affective Disorders. 2011;131(1-3):243-250.

11. Rogers J. P, Chesney E., Oliver D. et al. Психиатрические и психоневрологические проявления, связанные с тяжелой коронавирусной инфекцией: систематический обзор и метаанализ со сравнением с пандемией COVID19 // The Lancet, 2020. https://mentalcenter.kz/ru/index.php/pzt?layout=edit\&id=356. 